\title{
Screening antiproliferative drug for breast cancer from bisbenzylisoquinoline alkaloid tetrandrine and fangchinoline derivatives by targeting BLM helicase
}

Wangming Zhang ${ }^{1,2}$, Shuang Yang ${ }^{2}$, Jinhe Liü ${ }^{2,3}$ Linchun Bao ${ }^{2}$, He Lü ${ }^{4}$, Hong Li ${ }^{5}$, Weidong Pan ${ }^{6}$, Yanchao Jiao ${ }^{7}$, Zhixu He $\mathrm{H}^{3}$ and Jielin Liu $\mathrm{Li}^{2,3^{*}}$

\begin{abstract}
Background: The high expression of BLM (Bloom syndrome) helicase in tumors involves its strong association with cell expansion. Bisbenzylisoquinoline alkaloids own an antitumor property and have developed as candidates for anticancer drugs. This paper aimed to screen potential antiproliferative small molecules from 12 small molecules (the derivatives of bisbenzylisoquinoline alkaloids tetrandrine and fangchinoline) by targeting BLM ${ }^{642-1290}$ helicase. Then we explore the inhibitory mechanism of those small molecules on proliferation of MDA-MB-435 breast cancer cells.

Methods: Fluorescence polarization technique was used to screen small molecules which inhibited the DNA binding and unwinding of BLM ${ }^{642-1290}$ helicase. The effects of positive small molecules on the ATPase and conformation of BLM ${ }^{642-1290}$ helicase were studied by the malachite green-phosphate ammonium molybdate colorimetry and ultraviolet spectral scanning, respectively. The effects of positive small molecules on growth of MDA-MB-435 cells were studied by MTT method, colony formation and cell counting method. The mRNA and protein levels of BLM helicase in the MDA-MB-435 cells after positive small molecule treatments were examined by RT-PCR and ELISA, respectively.
\end{abstract}

Results: The compound HJNO (a tetrandrine derivative) was screened out which inhibited the DNA binding, unwinding and ATPase of BLM ${ }^{642-1290}$ helicase. That HJNO could bind BLM ${ }^{642-1290}$ helicase to change its conformationcontribute to inhibiting the DNA binding, ATPase and DNA unwinding of BLM ${ }^{642-1290}$ helicase. In addition, HJNO showed its inhibiting the growth of MDA-MB-435 cells. The values of $\mathrm{IC}_{50}$ after drug treatments for $24 \mathrm{~h}, 48 \mathrm{~h}$ and $72 \mathrm{~h}$ were $19.9 \mu \mathrm{mol} / \mathrm{L}, 4.1 \mu \mathrm{mol} / \mathrm{L}$ and $10.9 \mu \mathrm{mol} / \mathrm{L}$, respectively. The mRNA and protein levels of BLM helicase in MDAMB-435 cells increased after HJNO treatment. Those showed a significant difference $(P<0.05)$ compared with negative control when the concentrations of $\mathrm{HJNO}$ were $5 \mu \mathrm{mol} / \mathrm{L}$ and $10 \mu \mathrm{mol} / \mathrm{L}$, which might contribute to HJNO inhibiting the DNA binding, ATPase and DNA unwinding of BLM helicase.

Conclusion: The small molecule HJNO was screened out by targeting BLM ${ }^{642-1290}$ helicase. And it showed an inhibition on MDA-MB-435 breast cancer cells expansion.

Keywords: BLM helicase, HJNO, Fluorescence polarization, EMSA, MTT, RT-PCR, ELISA

\footnotetext{
* Correspondence: wdpan@163.com; liujlin63@yahoo.com

${ }^{6}$ State Key Laboratory of Functions and Applications of Medicinal Plants, Guizhou Medical University, 3491 Baijin Road, Guiyang 550014, People's Republic of China

${ }^{2}$ Department of Immunology, Basic Medical College, Guizhou Medical University, 9 Beijing Road, Guiyang 550004, People's Republic of China Full list of author information is available at the end of the article
}

(c) The Author(s). 2019 Open Access This article is distributed under the terms of the Creative Commons Attribution 4.0 International License (http://creativecommons.org/licenses/by/4.0/), which permits unrestricted use, distribution, and reproduction in any medium, provided you give appropriate credit to the original author(s) and the source, provide a link to the Creative Commons license, and indicate if changes were made. The Creative Commons Public Domain Dedication waiver (http://creativecommons.org/publicdomain/zero/1.0/) applies to the data made available in this article, unless otherwise stated. 


\section{Background}

As one of the biggest public health problems around the world, malignant tumors do great harm to human health and will become the first killer of human in the new century [1]. Conventional cancer treatments such as radiotherapy and chemotherapy cause great damage to normal cells as well as human themselves. Therefore, there is urgent need to develop safer anticancer drugs with fewer side effects.

RecQ helicase family is the most conservative family in the second largest superfamily of helicase. Their members play a pivotal role in keeping genetic stability of various organisms [2], such as DNA replication, repair, recombination, transcription and telomere stability. In humans, there are five kinds of RecQ helicase, those are, RecQ1, BLM, WRN, RecQ4 and RecQ5. The lack of three coding genes BLM, WRN and RecQ4 leads to occur related diseases, which are Bloom syndrome (BS), Werner syndrome (WS) and Rothmund-Thomson syndrome (RTS) [3-5], respectively. The patients of these diseases are commonly susceptible to cancer [6].

BLM helicase is an important member in RecQ helicase family. In human, BLM helicase expressed in various tumors from lymphocytes and epithelial cells. And the expressing BLM in tumors is higher than that in normal tissues [7, 8], implying its strong association with cell proliferation. In esophageal squamous cancer, BLM was reported 2.927 folds increased expression than normal mucosa [9]. Our previous research found the up-regulated expressions of BLM helicase in human leukemia cells and breast cancer cells [10]. Therefore, it provides a new clue to design and screen anticancer drugs by targeting BLM helicase [11-13].

Recently many studies were reported that focused on screening potential anticancer small molecules by inhibiting RecQ helicase. Robert M [14] found that telomycin A and netropsin could inhibit the BLM and WRN helicases. Monika [15] found that NSC 19630 (1propoxymethyl maleimide) also inhibited WRN helicase. Houqiang Xu [16-20] found that estradiol benzoate and testosterone propionate showed an inhibition on RecQ helicase in E. coli, lomefloxacin inhibited DNA unwinding and ATPase of BLM helicase, and $\mathrm{Hg}^{2+}$ also inhibited BLM helicase. According to the literatures, bisbenzylisoquinoline alkaloids have an antitumor property and have developed as candidates for anticancer drugs [21]. Tetrandrine and fangchinoline belong to bisbenzylisoquinoline alkaloids. In this paper, potential antiproliferative small molecules for breast cancer were screened out from 12 small molecules (the derivatives of bisbenzylisoquinoline alkaloids tetrandrine and fangchinoline) by targeting BLM helicase. Their inhibiting proliferation were further confirmed by the breast cancer cell growth test. The expressing BLM helicases in breast cancer cells after the small molecule treatments were examined by RT-PCR and ELISA, to explore the small molecule inhibiting cell expansion in breast cancer.

\section{Methods \\ Materials}

Recombinant E. coli pET-15b-BLM ${ }^{642-1290}$-BL21CodonPlus was a gift from Dr. Xuguang Xi [22]. MDAMB-435 breast cancer cells and human umbilical vein endothelial cells HUVECs were gifts from Dr. $\mathrm{He} \mathrm{Lu}$ [10] and preserved in the Laboratory of Tissue Engineering and Stem Cell of Guizhou Medical University.

\section{Instruments}

AKTA purifier 100 protein separation and purification system (GE Healthcare Co., USA). Beacon 2000 fluorescence polarization analyzer (PanVera LLC, USA). Synergy 4 microplate reader (BioTek Instruments, Inc., USA). SHIMADZU UV-3600 ultraviolet and visible spectrophotometer (Shimadzu Corp., Japan). VCX-500 ultrasonic processor (Sonics \& Materials, Inc., USA). Inverted microscope (Nikon Corp., Japan). Gradient thermal cycler (Eppendorf Co., Germany). Milli-Q ultra pure water system (Millipore Corp., USA).

\section{Chemistry}

Twelve derivatives of tetrandrine and fangchinoline such as HJNO were provided by Dr. Weidong Pan's group. Tetrandrine was selectively halogenated with NXS $(X=$ $\mathrm{Cl}, \mathrm{Br}$ ) in the presence of TFA to obtain compounds HL-5, HL-6, HL-7 and HL-8 [23] and nitrified to obtain compound HJNO [24]. HL-15 was also produced as a major by-product with two nitro groups. The nitro group in HJNO was then efficiently transformed into an amino group by $\mathrm{Pd} / \mathrm{C}$ in hydrazine hydrate to afford the amino compound, which was added the $\mathrm{RCOCl}$ to afford compounds HL-22, HL-24 and HL-27 [23]. HL-25 were synthesized from the amino compound by adding 4Methylbenzenesulfonyl chloride in pyridine [25]. Fangchinoline reacted with benzoyl chloride in THF in the presence of 4-dimethylaminopyridine (DMAP) to afford HL-23 [26]. Fangchinoline was protected with Bn group, then quaternary ammoniated using $\mathrm{BnBr}$ to give $\mathrm{HY}-2$.

HL-15 $\mathrm{C}_{38} \mathrm{H}_{40} \mathrm{~N}_{4} \mathrm{O}_{10}$ ESI-MS: $m / z 713.7[\mathrm{M}+\mathrm{H}]^{+} ;{ }^{1} \mathrm{H}$ $\operatorname{NMR}\left(\mathrm{CDCl}_{3}, 400 \mathrm{MHz}\right) \delta(\mathrm{ppm}): 7.42(1 \mathrm{H}, \mathrm{s}), 7.39(1 \mathrm{H}$, $\mathrm{dd}, J=2.4,8.4 \mathrm{~Hz}), 7.15(1 \mathrm{H}, \mathrm{dd}, J=2.8,8.4 \mathrm{~Hz}), 6.77$ $(1 \mathrm{H}, \mathrm{dd}, J=2.4,8.4 \mathrm{~Hz}), 6.55(1 \mathrm{H}, \mathrm{s}), 6.52(1 \mathrm{H}, \mathrm{s}), 6.30$ $(1 \mathrm{H}, \mathrm{dd}, J=2.0,8.4 \mathrm{~Hz}), 6.00(1 \mathrm{H}, \mathrm{s}), 3.99(3 \mathrm{H}, \mathrm{s}), 3.79$ $(3 \mathrm{H}, \mathrm{s}), 3.71-3.56(4 \mathrm{H}, \mathrm{m}), 3.44(3 \mathrm{H}, \mathrm{s}), 3.26(1 \mathrm{H}, \mathrm{m})$, $3.21(3 \mathrm{H}, \mathrm{s}), 2.96-2.77(7 \mathrm{H}, \mathrm{m}), 2.66(3 \mathrm{H}, \mathrm{s}), 2.47(2 \mathrm{H}$, $\mathrm{m}), 2.20(3 \mathrm{H}, \mathrm{s}) ;{ }^{13} \mathrm{C} \mathrm{NMR}\left(\mathrm{CDCl}_{3}, 100 \mathrm{MHz}\right) \delta(\mathrm{ppm})$ : $156.7,151.5,149.6148 .7,148.5,144.4,142.1,140.7,138.1$, $133.2,132.6,129.3,128.0,127.7,127.4,122.5,122.3$, 
$121.3,121.0,120.6,120.1,112.5,105.9100 .6,64.2,61.5$, $60.0,56.1,55.6,55.5,45.0,43.2,42.3,40.8,40.0,38.7$, 24.6, 20.6 .

HY-2 $\mathrm{C}_{51} \mathrm{H}_{53} \mathrm{~N}_{2} \mathrm{O}_{6}$ ESI-MS: $m / z 790.5[\mathrm{M}+\mathrm{H}]^{+} ;{ }^{1} \mathrm{H}$ NMR $\left(\mathrm{CDCl}_{3}, 400 \mathrm{MHz}\right) \delta$ (ppm): $7.60(2 \mathrm{H}, \mathrm{d}, J=7.2$ $\mathrm{Hz}), 7.40(2 \mathrm{H}, \mathrm{m}), 7.17(5 \mathrm{H}, \mathrm{m}), 7.02(1 \mathrm{H}, \mathrm{dd}, J=2.4,8.0$ $\mathrm{Hz}), 6.98(1 \mathrm{H}, \mathrm{d}, J=8.4 \mathrm{~Hz}), 6.90(1 \mathrm{H}, \mathrm{d}, J=2.0 \mathrm{~Hz}), 6.88$ $(1 \mathrm{H}, \mathrm{d}, J=4.0 \mathrm{~Hz}), 6.80(1 \mathrm{H}, \mathrm{d}, J=8.4 \mathrm{~Hz}), 6.65(1 \mathrm{H}, \mathrm{s})$, $6.55(1 \mathrm{H}, \mathrm{dd}, J=2.4,8.0 \mathrm{~Hz}), 6.53(1 \mathrm{H}, \mathrm{s}), 6.48(1 \mathrm{H}, \mathrm{dd}$, $J=2.4,8.0 \mathrm{~Hz}), 6.33(1 \mathrm{H}, \mathrm{d}, J=2.0 \mathrm{~Hz}), 5.68(1 \mathrm{H}, \mathrm{s}), 5.34$ $(1 \mathrm{H}, \mathrm{d}, J=12.4 \mathrm{~Hz}), 4.98(1 \mathrm{H}, \mathrm{d}, J=10.0 \mathrm{~Hz}), 4.58(1 \mathrm{H}, \mathrm{d}$, $J=10.8 \mathrm{~Hz}), 4.41(1 \mathrm{H}, \mathrm{d}, J=10.8 \mathrm{~Hz}), 3.89(3 \mathrm{H}, \mathrm{s}), 3.80$ $(3 \mathrm{H}, \mathrm{s}), 3.76(1 \mathrm{H}, \mathrm{d}, J=4.8 \mathrm{~Hz}), 3.50(3 \mathrm{H}, \mathrm{m}), 3.44(3 \mathrm{H}$, s), $3.40-2.85(8 \mathrm{H}, \mathrm{m}), 2.83(3 \mathrm{H}, \mathrm{s}), 2.76(2 \mathrm{H}, \mathrm{m}), 2.60$ $(3 \mathrm{H}, \mathrm{s}) ;{ }^{13} \mathrm{C} \mathrm{NMR}\left(\mathrm{CDCl}_{3}, 100 \mathrm{MHz}\right) \delta$ (ppm): 153.7, $153.0,149.8,148.1,147.8,146.9,142.2,137.5,136.5$, $135.6,133.2,133.2,132.0,131.1,130.4,130.4,128.8$, $128.8,128.4,128.4,128.1,128.1,128.0,128.0,127.5$, $124.3,123.2,122.4,122.3,119.6,116.0,112.7,112.3$, $112.1,106.1,74.9,64.5,64.2,64.1,56.2,56.1,55.8,54.9$, 51.1, 45.4, 42.3, 40.5, 40.0, 29.8, 24.9, 24.0.

\section{Reagents}

Positive control mitomycin C (MMC) was from Sigma (USA). $45 \mathrm{nt}$ single stranded DNA (ssDNA, A1: 5' AATCCGTCGAGCAGAGTTAGGTTAGGTTAG

GTTAGTTTTTTTTTT-3') and fluorescein-labled $21 \mathrm{nt}$ single stranded DNA (ssDNA, A2: 3'-FAM-TTAGGC AGCTCGTCTCAATCC-5') were synthesized by Beijing Ding Guo Chang sheng Biotechnology Inc. Two complementary ssDNAs were equally mixed in buffer (20 $\mathrm{mmol} / \mathrm{L}$ Tris, $100 \mathrm{mmol} / \mathrm{L} \mathrm{NaCl}, \mathrm{pH}$ 7.9) and water bath at $85^{\circ} \mathrm{C}$ for $5 \mathrm{~min}$. After cooled at room temperature, renaturated double stranded DNA (dsDNA, A1A2) was used as a substrate to detect DNA binding and unwinding of BLM helicase. RPMI-1640 was from Gibco (USA); MTT was from Sigma(USA). Total RNA extraction kit was from Tiangen (China). M-MLV first strand synthesis system reverse transcription kit was from Invitrogen (USA). PCR primers for amplification of $B L M$ gene were synthesized by Beijing Ding Guo Biotechnology. The sequence was as follows, forward: 5'-GGATCCTGGTTCCGTCCGC-3', reverse: 5'-CCTCAGT-CAAATC TATTTGCTCG-3'.PCR product of BLM was $708 \mathrm{bp}$ [27]. $\beta$-actin was used as internal control. Its sequence was as follows, forward: 5'-CGGAGTCAA-CGGATT TGGTCGTAT-3', reverse: 5'-AGCCTTCTC-GATGGT GGTGAAGAC-3'. PCR product of $\beta$-actin was $306 \mathrm{bp}$. Human BLM ELISA kit was from HuaMei Inc. (Wuhan, China). 30\% acrylamide and bisacrlamide, TEMED, APS, Glycerol, Tris, bromophenol blue are all from Beijing Solebo Technology Co., Ltd. 5 x TBE buffer was from Beijing Regen Biotechnology Co., Ltd.
Expression and purification of BLM ${ }^{642-1290}$ helicase

Recombinant E. coli pET-15b-BLM ${ }^{642-1290}$-BL21-CodonPlus was seeded into LB media (containing $50 \mu \mathrm{g} / \mathrm{mL}$ Ampicillin $+30 \mu \mathrm{g} / \mathrm{mL} \mathrm{Cam}$ ) and cultured in a shaker incubator for $190 \mathrm{rpm}$ at $37^{\circ} \mathrm{C}$ until $\mathrm{OD}^{600}$ reached $0.5-$ 0.6. Expressing BLM helicase was induced by $0.4 \mathrm{mM}$ IPTG for $20 \mathrm{~h}\left(18^{\circ} \mathrm{C}, 190 \mathrm{rpm}\right)$. After that, bacteria were collected by $4000 \mathrm{rpm}$ centrifuge at $4{ }^{\circ} \mathrm{C}$ for $20 \mathrm{~min}$, then ultrasonicated and the supernatant was collected by 13 , $000 \mathrm{rpm}$ centrifuge at $4{ }^{\circ} \mathrm{C}$ for $40 \mathrm{~min}$. The recombinant BLM $^{642-1290}$ helicase used for enzymatic study was harvested after purification by nickel ion affinity chromatography and gel filtration chromatography. Based on the bromophenol blue-stained 10\% SDS-PAGE analysis, the purity of the helicase product was above $95 \%$.

\section{Screening derivatives of tetrandrine and fangchinoline with inhibiting BLM helicase by fluorescence polarization method}

We performed fluorescence polarization method to find out the effects of small molecules on the binding between dsDNA and BLM helicase. At first, we added 2 $\mathrm{nmol} / \mathrm{L}$ fluorescein labeled dsDNA into reaction buffer ( $20 \mathrm{mmol} / \mathrm{L}$ Tris, $25 \mathrm{mmol} / \mathrm{L} \mathrm{NaCl}, 3 \mathrm{mmol} / \mathrm{L} \mathrm{MgCl}_{2}$, $0.1 \mathrm{mmol} / \mathrm{L} \mathrm{DTT}, \mathrm{pH}$ 7.9) to detect fluorescence anisotropy value in the fluorescence polarization analyzer until it was stable. After that, we added small molecules with different concentrations $(0-6.67 \mu \mathrm{mol} / \mathrm{L})$ and detected fluorescence anisotropy value until it was stable. Finally, $500 \mathrm{nmol} / \mathrm{L}$ BLM helicase was added to make DNA substrate soaked and fluorescence anisotropy value was also detected. Total reaction volume was $150 \mu \mathrm{L}$ by adjusting dd $\mathrm{H}_{2} \mathrm{O}$ volume.

\section{Detection of the effect of HJNO on DNA binding and unwinding of $\mathrm{BLM}^{642-1290}$ helicase determined by fluorescence polarization method}

We added $2 \mathrm{nmol} / \mathrm{L}$ fluorescence labeled DNA [dsDNA or ssDNA (21 nt)] into reaction buffer $(20 \mathrm{mmol} / \mathrm{L}$ Tris, $25 \mathrm{mmol} / \mathrm{L} \mathrm{NaCl}, 3 \mathrm{mmol} / \mathrm{L} \mathrm{MgCl}_{2}, 0.1 \mathrm{mmol} / \mathrm{L} \mathrm{DTT}$, $\mathrm{pH}$ 7.9) to detect fluorescence anisotropy value until it was stable. Then we added HJNO with different concentrations $(0-33.34 \mu \mathrm{mol} / \mathrm{L})$ and deccted fluorescence anisotropy value until it was stable. At last $500 \mathrm{nmol} / \mathrm{L}$ BLM helicase was added to make DNA substrate soaked and fluorescence anisotropy value was also detected until it was stable. The fluorescence anisotropy values were recorded.

We detected $\mathrm{HJNO}$ affecting DNA unwinding of BLM $^{642-1290}$ helicase by using same protocol. The final concentration of $\mathrm{HJNO}$ here was $0-50 \mu \mathrm{mol} / \mathrm{L}$. In addition, in the final step, we added $0.2 \mathrm{mmol} / \mathrm{L}$ ATP instead of $500 \mathrm{nmol} / \mathrm{L}$ BLM helicase. 
Detection of the effect of HJNO on DNA binding of BLM $^{642-1290}$ helicase determined by EMSA

We added $500 \mu \mathrm{mol} / \mathrm{L}$ fluorescence labeled DNA [dsDNA] into reaction buffer $(20 \mathrm{mmol} / \mathrm{L}$ Tris, $25 \mathrm{mmol} / \mathrm{L} \mathrm{NaCl}, 3$ $\mathrm{mmol} / \mathrm{L} \mathrm{MgCl}_{2}, 0.1 \mathrm{mmol} / \mathrm{L}$ DTT, $\mathrm{pH}$ 7.9). Then we added $\mathrm{HJNO}$ with different concentrations $(0-3.35 \mu \mathrm{mol} / \mathrm{L})$ and $2.5 \mu \mathrm{mol} / \mathrm{L} \mathrm{BLM}^{642-1290}$ helicase respectively to make DNA substrate soaked. All reaction tubes incubated for 45 $\mathrm{min}$ at room temperature. After $45 \mathrm{~min}$, each tube was added $4 \mu \mathrm{l}$ loading buffer to end the reaction. We loaded the samples and taken $200 \mathrm{v}$ constant voltage electrophoresis for $30 \mathrm{~min}$. Then we observed and recorded the results on the Bio-rad ChemiDoc ${ }^{\text {nt }}$ Imaging System.

The effect of HJNO on the ATPase of BLM ${ }^{642-1290}$ helicase detected by malachite green-phosphate and ammonium molybdate colorimetry

We mixed $125 \mathrm{nmol} / \mathrm{L}$ BLM helicase, $100 \mathrm{nmol} / \mathrm{L}$ ssDNA $(45 \mathrm{nt})$ and various $\mathrm{HJNO}$ solutions $(0-100 \mu \mathrm{mol} / \mathrm{L})$ into reaction buffer respectively. The total reaction volume was $75 \mu \mathrm{L}$ by adjusting $\mathrm{ddd}_{2} \mathrm{O}$ volume. We incubated the mixture at room temperature for $10 \mathrm{~min}$. Then we added 2 $\mathrm{mmol} / \mathrm{L}$ ATP into the mixture and incubated it at room temperature for $20 \mathrm{~min}$. Fifty microliter mixture was quickly added into $850 \mu \mathrm{L}$ dye to terminate the ATP hydrolysis reaction. After $1 \mathrm{~min}, 100 \mu \mathrm{L} 34 \%$ citric acid solution was added to stop color reaction. After that, we added the $100 \mu \mathrm{L}$ mixture into one well of a 96-well plate and read three repeated wells at the length of $660 \mathrm{~nm}$. The international unit was applied to define the enzyme amount. That is, a unit of enzyme is needed to hydrolyze $1 \mu \mathrm{mol}$ substrate per minute. The enzymatic amount (units/mL) was calculated as: $A_{\text {activity }}=\frac{3 A}{10 B}$.

A was the phosphate concentration $(\mu \mathrm{mol} / \mathrm{L})$ calculated by standard curve. B was reaction time (min).

Relative ATPase activity was equal to the ratio of ATPase activity of BLM helicase treated with HJNO and ATPase activity of that without any treatment.

\section{The effect of HJNO on the ultraviolet spectrum of $\mathrm{BLM}^{642-}$ ${ }^{1290}$ helicase}

We mixed $500 \mathrm{nmol} / \mathrm{L}$ BLM helicasewith various $\mathrm{HJNO}$ solutions $(0-50 \mu \mathrm{mol} / \mathrm{L})$ in Tris- $\mathrm{HCl}$ buffer ( $\mathrm{pH}$ 7.9) respectively. And the total reaction volume was $3000 \mu \mathrm{L}$. Then the mixture was scanned by the ultraviolet spectrophotometer at $220-380 \mathrm{~nm}$. The length interval was $0.5 \mathrm{~nm}$ and the scanning speed was medium. The scanning interval was 3 min until it was stable. Whether protein conformation changed could be determined by changes of peak shape and position [28, 29]. In addition, we used the same method to scan the ultraviolet absorption spectra of various $\mathrm{HJNO}$ solutions $(0-50 \mu \mathrm{mol} / \mathrm{L})$ in the buffer respectively.

\section{HJNO inhibiting MDA-MB-435 breast cancer cells expansion \\ MTT method}

We seeded MDA-MB-435 breast cancer cells into 96well plate at the density of $8 \times 10^{3}$ each well and cultured for $12 \mathrm{~h}$ when they were adherent. Then we addedHJNO solutions with different concentrations $(0.5 \mu \mathrm{mol} / \mathrm{L}$, $2.5 \mu \mathrm{mol} / \mathrm{L}, 5 \mu \mathrm{mol} / \mathrm{L}, 25 \mu \mathrm{mol} / \mathrm{L}$ and $50 \mu \mathrm{mol} / \mathrm{L})$ respectively. RPMI-1640 complete medium and MMC with the same gradient concentrations as those of $\mathrm{HJNO}$ solutions were used as negative control and positive control, respectively. Triplicates were performed. The cells were cultured for $24 \mathrm{~h}, 48 \mathrm{~h}$ and $72 \mathrm{~h}$, respectively. Then we added MTT solution and continued to incubate it for $4 \mathrm{~h}$. After crystalline substance was completely dissolved by DMSO, the automatic microplate reader was used to detect the OD value of each well (wavelength was 490 $\mathrm{nm})$. The inhibition ratio and $\mathrm{IC}_{50}(50 \%$ inhibiting concentration) of drug on the cell expansion were calculated according to the OD values.

\section{Cell colony formation}

We seeded MDA-MB-435 cells into 24-well plate at the density of 350 each well added of HJNO solutions with different concentrations $(0.5 \mu \mathrm{mol} / \mathrm{L}, 2.5 \mu \mathrm{mol} / \mathrm{L}$ and $5 \mu \mathrm{mol} / \mathrm{L}$ ) respectively. Triplicates were performed. RPMI-1640 complete medium and MMC were used as negative control and positive control, respectively. We had cultured the cells for 7 days. After washed by PBS, cells were fixed by methanol and stained by trypan blue. We calculated the colony forming ratio and colony inhibiting ratio after counting the colonies.

$$
\begin{aligned}
\text { Colony forming ratio }= & (\text { the number of colonies } / \\
& \text { the number of seeded cells }) \times 100 \%
\end{aligned}
$$

Colony inhibiting ratio $=(1-($ colony forming ration in the experimental group $/$ colony forming ratio in thecontrol group) $) \times 100 \%$.

\section{Cell counting}

We cultured and treatedMDA-MB-435 cells as above. After decanting medium, cells were washed by PBS three times and digested by $0.25 \%$ trypsin. We added medium with $10 \%$ serum to stop the digestion and added $10 \mu \mathrm{L}$ cell suspension to the cell count plate and then counted the number of cells. The total cell count was calculated by the following equation: Total cell count $=\mathrm{N} / 4 \times 104 / \mathrm{mL} \times 0.5 \mathrm{~mL}$ $(\mathrm{N}$ : the number of cells in the four large squares at the four corners). 
The effect of HJNO on the expression of BLM helicase in the MDA-MB-435 breast cancer cells

The mRNA and protein expression of BLM was detected by RT-PCR and ELISA according to the kit instruction, respectively.

\section{Statistical analysis}

All data are analyzed using SPSS 17.0 statistical software. Compared with BLM expression level in the drug treated group and without drug control group, two independent sample $t$ tests were used to indicate that the difference was statistically significant with $P<0.05$.

\section{Results}

Screening out small molecules with inhibiting BLM ${ }^{642-1290}$ helicase from 12 derivatives of tetrandrine and fangchinoline

When concentration of small molecules was $6.67 \mu \mathrm{mol} /$ $\mathrm{L}$, among 12 derivatives of tetrandrine and fangchinoline, the inhibiting values of HL-22, HJNO, HL-6, HL-27 and HY-2 on BLM ${ }^{642-1290}$ helicase binding to dsDNA were 14, 19, 30, 47 and 65, respectively (Fig. 1). According to results showed in Fig. 1, we slected and used Tetrandrine $\mathrm{HJNO}$ for following experiments.

\section{The effect of HJNO on the DNA binding of BLM ${ }^{642-1290}$ helicase}

As shown in Fig. 2a, HJNO bound to dsDNA or ssDNA (21 nt) to form a complex. HJNO could inhibit BLM helicase binding to dsDNA or ssDNA (21 nt) and the inhibiting constant (Ki) value was $12.89 \pm 3.59 \mu \mathrm{M}$ or $21.39 \pm 1.76 \mu \mathrm{M}$ (Fig. 2b). When concentration of HJNO

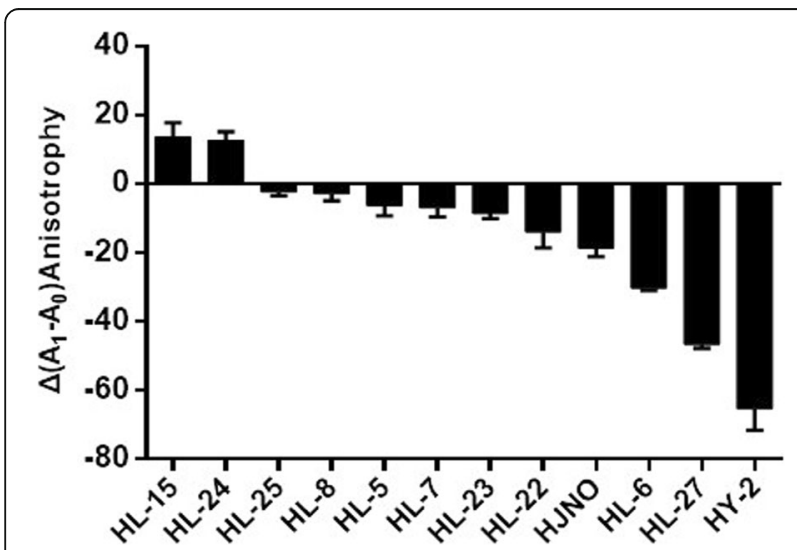

Fig. 1 Effects of the derivatives of tetrandrine and fangchinoline on dsDNA binding of BLM ${ }^{642-1290}$ helicase. Note: $A 0$ is the fluorescence anisotrophy of dsDNA binding small molecules. A1 is the fluorescence anisotrophy of the complexes which is formed by BLM $^{642-1290}$ binding dsDNA and small molecules. $\Delta(A 1-A 0)$ is the differences between the activities of BLM helicase binding dsDNA which is treated by small molecules or not. Data were means \pm SD with five replicates and the same below was $33.34 \mu \mathrm{M}$, the inhibiting ratio of $\mathrm{HJNO}$ on BLM helicase binding to dsDNA or ssDNA (21 nt) was $42.42 \%$ or $46.72 \%$. While MMC did not bind to dsDNA nor ssDNA (21 nt) (Fig. 2c). MMC had no significant effect on BLM helicase binding to dsDNA and a weak inhibiting effect on BLM helicase binding to ssDNA (21 nt) with the Ki value of $3.62 \pm 0.84 \mu \mathrm{mol} / \mathrm{L}$ (Fig. 2d). When concentration of MMC was $6.67 \mu \mathrm{mol} / \mathrm{L}$, its inhibiting ratio on BLM helicase binding to ssDNA (21 nt) was $8 \%$. As shown in Fig. 2e and f, HJNO suppressed dsDNA binding to $\mathrm{BLM}^{642-1290}$ helicase at $0.335 \mu \mathrm{mol} / \mathrm{L}$ and $3.35 \mu \mathrm{mol} / \mathrm{L}$ as consistent with the results detected by fluorescence polarization method. MMC had no significant effect on BLM ${ }^{642-1290}$ helicase binding to dsDNA detected by EMSA, when concentrations of MMC was $0.5 \mu \mathrm{mol} / \mathrm{L}$ and $5 \mu \mathrm{mol} / \mathrm{L}$. These results were consistent with the results detected by fluorescence polarization method. But when concentrations of MMC were lower than $0.05 \mu \mathrm{mol} / \mathrm{L}$, they could inhibit $\mathrm{BLM}^{642-1290}$ helicase binding to dsDNA. (Fig. $2 g$ and $h$ ).

\section{The effect of HJNO on DNA unwinding of BLM ${ }^{642-1290}$ helicase}

HJNO could inhibit DNA unwinding of BLM helicase, whose $\mathrm{Ki}$ value was $15.62 \pm 0.74 \mu \mathrm{mol} / \mathrm{L}$. When concentration of $\mathrm{HJNO}$ was $50 \mu \mathrm{mol} / \mathrm{L}$, its inhibiting ratio on DNA unwinding of BLM helicase reached $85.74 \%$ (Fig. 3a and b). In addition HJNO also exerted an inhibiting effect on DNA unwinding rate of BLM helicase (Fig. 3b).

MMC had a little inhibitory effect on DNA unwinding of BLM helicase as well, whose $\mathrm{Ki}$ value was $0.35 \pm$ $0.03 \mu \mathrm{mol} / \mathrm{L}$ (Fig. $3 \mathrm{c}$ and d). When concentration of $\mathrm{MMC}$ was $1.5 \mu \mathrm{mol} / \mathrm{L}$, its inhibiting ratio on DNA unwinding of BLM helicase was $49.20 \%$. However, when MMC concentration exceeded $1.5 \mu \mathrm{mol} / \mathrm{L}, \quad \mathrm{MMC}$ inhibiting DNA unwinding of BLM helicase decreased.

\section{The effect of HJNO on the ATPase activity of BLM ${ }^{642-1290}$ helicase}

When concentration of $\mathrm{HJNO}$ was $100 \mu \mathrm{mol} / \mathrm{L}$, its inhibiting ratio on the ATPase activity of BLM helicase was $32.8 \%$, while that of MMC was $40.4 \%$ when its concentration was $100 \mu \mathrm{mol} / \mathrm{L}$ (Fig. 4).

The effect of HJNO on the ultraviolet spectrum of BLM ${ }^{642-}$ 1290 helicase

As shown in Fig. 5b, the ultraviolet absorption values at $237 \mathrm{~nm}$ and $277 \mathrm{~nm}$ after HJNO interacting with $\mathrm{BLM}^{642-1290}$ helicase were more than the sum of those of $\mathrm{HJNO}$ and BLM ${ }^{642-1290}$ at the same wavelength. It was caused by the chromophore of BLM helicase flipping to a greater polar domain [25]. The ultraviolet absorption values at $237 \mathrm{~nm}$ and $277 \mathrm{~nm}$ after HJNO interacting with $\mathrm{BLM}^{642-1290}$ helicase increased with the 

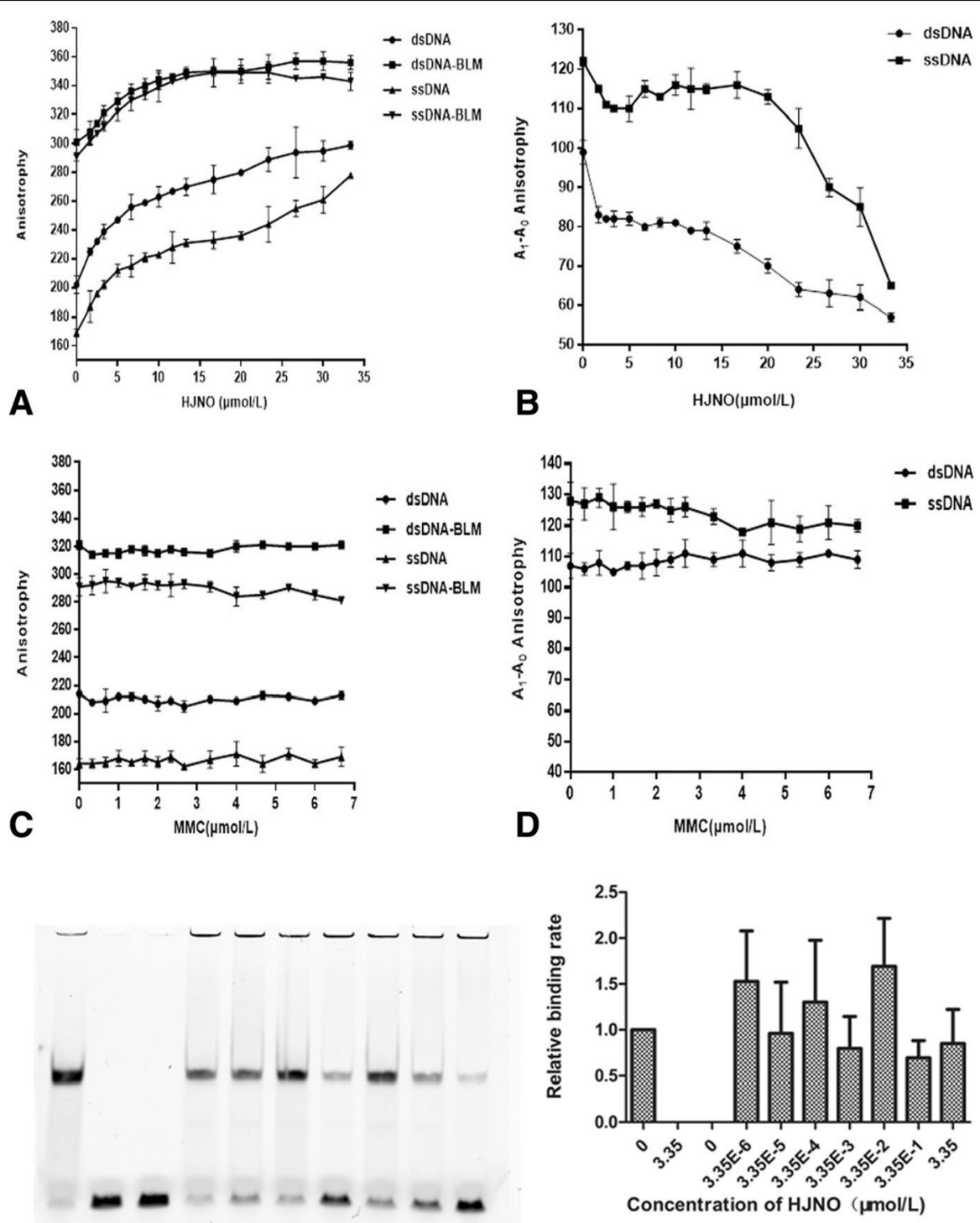

$\mathbf{E}$

$\mathbf{F}$
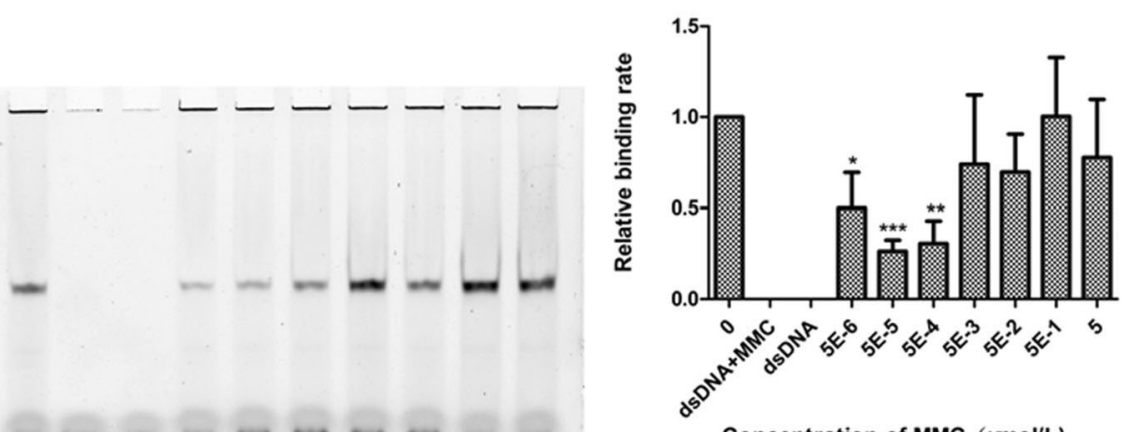

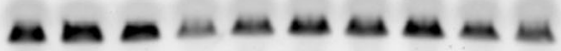

G

H 
(See figure on previous page.)

Fig. 2 Effects of HJNO and MMC on the DNA binding of BLM ${ }^{642-1290}$ helicase. a Effects of HJNO on fluorescence anisotrophy of dsDNA or ssDNA (21 nt) and complexes of BLM ${ }^{642-1290}$ binding dsDNA or ssDNA (21 nt). b Effects of HJNO on the dsDNA or ssDNA (21 nt) binding of BLM ${ }^{642-1290}$ helicase. $\mathbf{c}$ Effects of MMC on fluorescence anisotrophy of dsDNA or ssDNA (21 nt) and complexes of BLM ${ }^{642-1290}$ binding dsDNA or ssDNA (21 $\mathrm{nt}$ ). $\mathbf{d}$ Effects of MMC on the dsDNA or ssDNA (21 nt) binding of BLM ${ }^{642-1290}$ helicase. e, $\mathbf{f}$ Effects of HJNO on complexes of BLM ${ }^{642-1290}$ binding dsDNA detected by EMSA and statistic results. $\mathbf{g}$, $\mathbf{h}$ Effects of MMC on complexes of BLM ${ }^{642-1290}$ binding dsDNA detected by EMSA and statistic results. Note: $A_{0}$ is the fluorescence anisotrophy of DNA binding small molecular substances. $A_{1}$ is the fluorescence anisotrophy of complexes which is formed by BLM binding DNA and small molecules

increasing of HJNO concentration (Fig. 5a). These results suggested that HJNO bound to BLM ${ }^{642-1290}$ helicase and changed its conformation.

The ultraviolet absorption values at $237 \mathrm{~nm}, 277 \mathrm{~nm}$ and $365 \mathrm{~nm}$ after MMC interacting with $\mathrm{BLM}^{642-1290}$ helicase nearly equaled to the sum of the ultraviolet absorption values of MMC and $\mathrm{BLM}^{642-1290}$ helicase at these three wavelengths. It suggested that MMC did not change BLM ${ }^{642-1290}$ helicase conformation (Fig. 5d). The ultraviolet absorption values at $237 \mathrm{~nm}$ and $365 \mathrm{~nm}$ also increased with MMC concentration increasing, while the ultraviolet absorption peak at $277 \mathrm{~nm}$ gradually disappeared (Fig. 5c), which was caused by the lack of phenyl group in MMC. The ultraviolet absorption peak still formed by the aromatic residue of $\mathrm{BLM}^{642-1290}$ helicase, while BLM $^{642-1290}$ helicase concentration did not increase. Therefore, MMC exerted no effect on BLM ${ }^{642-}$ ${ }^{1290}$ helicase conformation.

\section{Inhibiting of HJNO on MDA-MB-435 breast cancer cell expansion}

The results from MTT test showed that inhibiting ratios of HJNO on expansion of MDA-MB-435 cells increased with HJNO concentration increasing. When HJNO concentrations were $25 \mu \mathrm{mol} / \mathrm{L}$ and $50 \mu \mathrm{mol} / \mathrm{L}$, its inhibiting ratios for $48 \mathrm{~h}$ and $72 \mathrm{~h}$ reached around $80 \%$ (Fig. 6i).
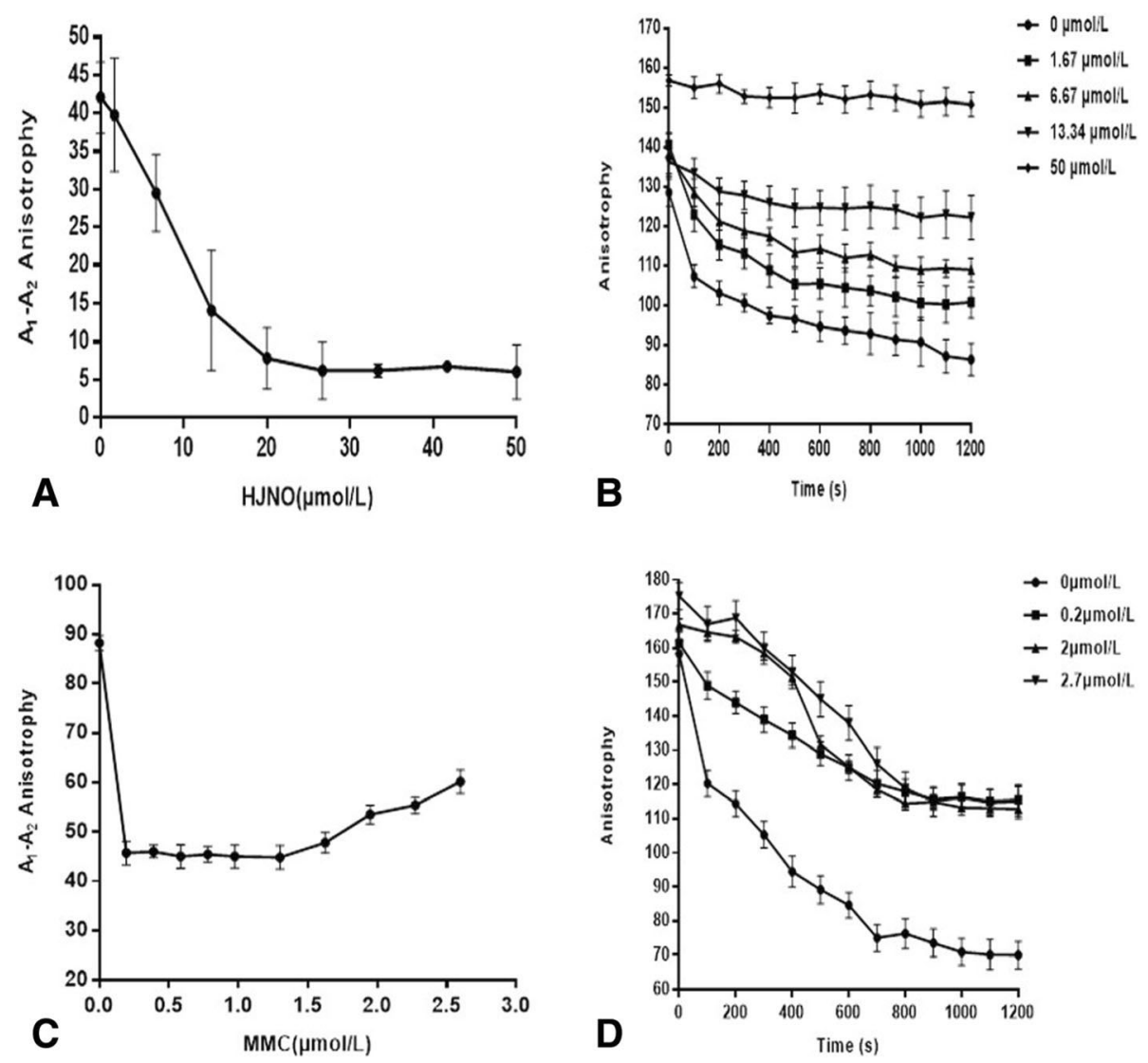

Fig. 3 Effects of HJNO or MMC on DNA unwinding of BLM helicase. aThe effects of HJNO on DNA unwinding of BLM helicase. $\mathbf{b}$ The effects of $1.67,6.67,13.34$ and $50 \mu \mathrm{mol} / \mathrm{L}$ HJNO on DNA unwinding time curve of BLM helicase. c The effects of MMC on DNA unwinding of BLM helicase; d The effects of $0.2,2$ and $2.7 \mu \mathrm{mol} / \mathrm{L}$ MMC on DNA unwinding time curve of BLM helicase. Note: A1 is the fluorescence anisotrophy of BLM binding DNA and small molecules. A2 is the fluorescence anisotrophy after adding $0.2 \mathrm{mmol} / \mathrm{L}$ ATP 


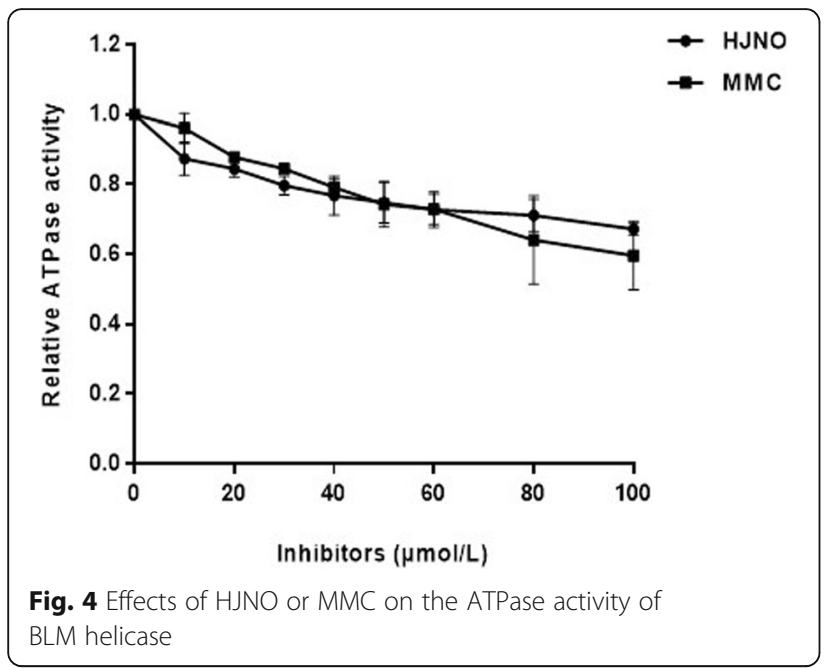

$\mathrm{IC}_{50}$ values of $\mathrm{HJNO}$ on the MDA-MB-435 cells for 24 $\mathrm{h}, 48 \mathrm{~h}$ and $72 \mathrm{~h}$ were $19.9 \mu \mathrm{mol} / \mathrm{L}, 4.1 \mu \mathrm{mol} / \mathrm{L}$ and $10.9 \mu \mathrm{mol} / \mathrm{L}$, respectively, while those of positive control MMC were $30.9 \mu \mathrm{mol} / \mathrm{L}, 7 \mu \mathrm{mol} / \mathrm{L}$ and $4.9 \mu \mathrm{mol} / \mathrm{L}$. The above results showed that inhibiting of HJNO for $24 \mathrm{~h}$ and $48 \mathrm{~h}$ were stronger than MMC, while MMC exceeded HJNO for $72 \mathrm{~h}$. This suggested that HJNO had a stronger inhibiting on MDA-MB-435 cells expansion in a short time.

Cell counting also showed HJNO inhibiting MDA-MB435 cells expansion. The inhibiting ratio reached $98.72 \%$ when HJNO's concentration was $5 \mu \mathrm{mol} / \mathrm{L}$ (Fig. 6II).

The results from colony forming assay showed that HJNO inhibited MDA-MB-435 cell forming colonies. When $\mathrm{HJNO}$ concentrations were $0.5 \mu \mathrm{mol} / \mathrm{L}, 2.5 \mu \mathrm{mol} /$ $\mathrm{L}$ and $5 \mu \mathrm{mol} / \mathrm{L}$, the colony inhibiting ratios of $\mathrm{HJNO}$ on the MDA-MB-435 cells were $74,93.4$ and $100 \%$, respectively (Fig. 6III, IV).

\section{The effect of HJNO on the expression of BLM helicase in the MDA-MB-435 cell line}

The RT-PCR results (Fig. 7a) showed that BLM helicase mRNA in MDA-MB-435 cells after HJNO treatment for $24 \mathrm{~h}$ was significantly higher than that in HUVEC cells. $(P<0.05)$ When the concentrations of $\mathrm{HJNO}$ were $5 \mu \mathrm{mol} / \mathrm{L}$ and $10 \mu \mathrm{mol} / \mathrm{L}$, BLM mRNA was significantly higher than that without HJNO $(P<0.05)$.

The results from ELISA test (Fig. 7b) showed that BLM helicase protein expression increased in MDAMB-435 cells with HJNO treatment for $24 \mathrm{~h}$. When HJNO concentration reached $10 \mu \mathrm{mol} / \mathrm{L}, \mathrm{BLM}$ protein expression was significantly higher than that without HJNO treatment $(P<0.01)$.

\section{Discussion}

Some conservative domains in the RecQ helicases have been identified by sequence analysis. They are unwinding domain (Helicase), RecQ conservative domain (RecQ-Ct) and helicase-ribonuclease D-C terminal domain (HRDC) [30, 31]. HRDC domain is mainly responsible for DNA binding. Helicase domain can not only unwind dsDNA but also show an ATPase activity that binds to ATP and hydrolyze it to release energy. RecQ-Ct domain plays a role in regulating DNA binding and interaction between proteins. Up to now, the common methods for detecting the DNA binding and unwinding of RecQ helicase are fluorescence polarization method, electrophoresis after unwinding the labed DNA and autoradiography. In the present study, we used fluorescence polarization technology, which could intuitively monitored the biological process of BLM ${ }^{642-1290}$ binding and unwinding dsDNA. When used in drug screening, It will realtime track and detect the drug-DNA interaction, the effect of drug on the DNA binding of BLM ${ }^{642-1290}$ helicase, as well as the effect of drug on the dsDNA unwinding of $\mathrm{BLM}^{642-1290}$ helicase.

\section{Tetrandrine derivative HJNO inhibiting DNA unwinding of BLM helicase}

Double benzyl isoquinoline alkaloids have anticancer effect and have developed as anticancer drugs [32]. Both tetrandrine and fangchinoline belong to double benzyl isoquinoline alkaloids. Tetrandrine has inhibiting effect on breast cancer [33], prostate cancer cells [34], neuroblastoma TGW [35] and colon cancer cells [36, 37]. Therefore, our study applied BLM ${ }^{642-1290}$ helicase inhibiting model and screened out anticancer small molecules from the derivatives of double benzyl isoquinoline alkaloids tetrandrine and fangchinoline. The results showed that we preliminarily screened out five small molecules with inhibiting DNA binding of BLM ${ }^{642-1290}$ helicase from 12 derivatives of double benzyl isoquinoline alkaloids. HL-6, HJNO, HL-22 and HL-27 were derivatives of tetrandrine while HY-2 was a fangchinoline derivative.

Anticancer by targeting DNA helicase is that drug interacts with DNA and changes it to interfere DNA helicase. It influences various kinds of cell biological activity such as DNA replication, repair and transcription [11,38], which is also the primary idea for screening potential anticancer small molecules by $\mathrm{BLM}^{642-1290}$ helicase inhibiting model. Our study revealed that HJNO could bind to both fluorescence labeled ssDNA and dsDNA, and its binding with ssDNA was stronger than dsDNA. DNA structure was modified by binding with HJNO, thus DNA binding to BLM ${ }^{642-1290}$ helicase was inhibited. HJNO inhibiting BLM ${ }^{642-1290}$ helicase binding with ssDNA was stronger than that with dsDNA, which was consistent with the statement that HJNO binding with ssDNA was stronger than that with dsDNA. Compared with dsDNA, HJNO occupied more BLM ${ }^{642-1290}$ helicase binding sites to ssDNA when binding with it, 

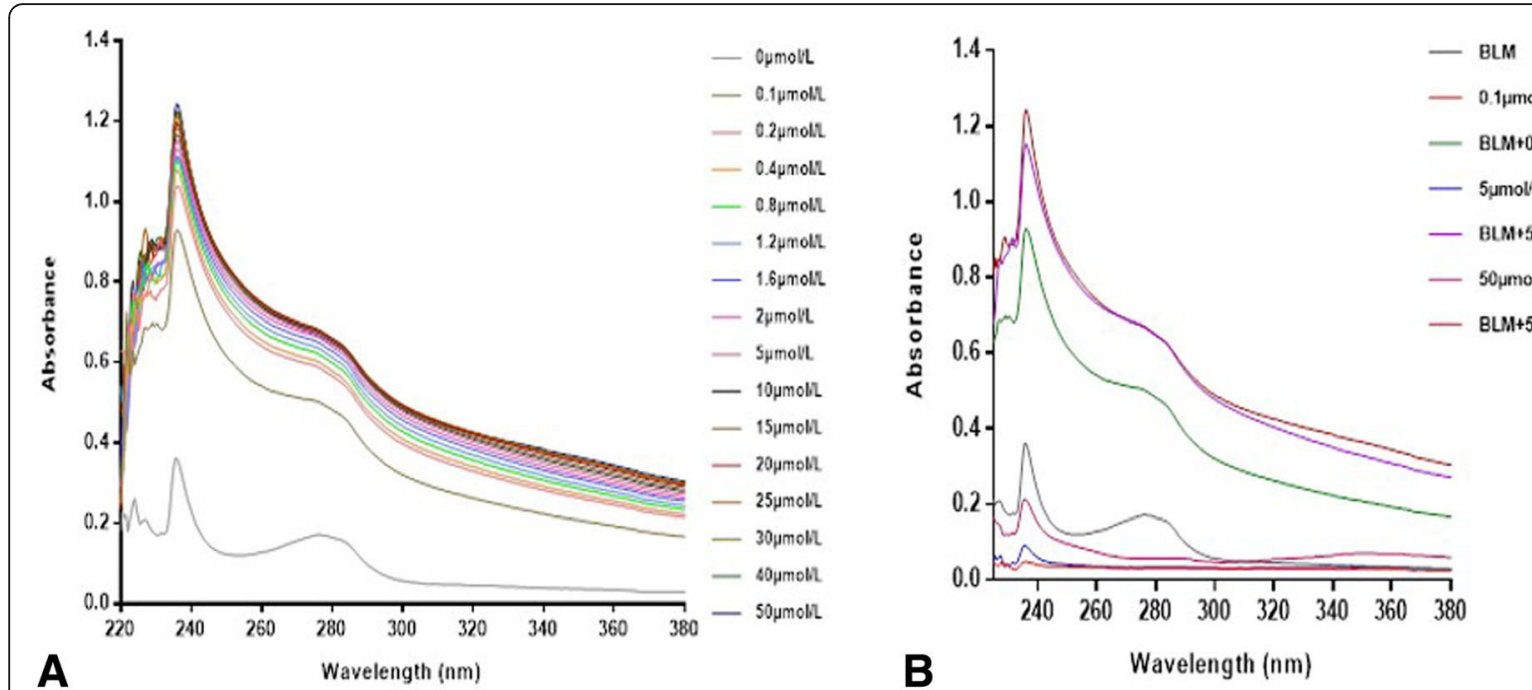

- $0.1 \mu \mathrm{mol} / \mathrm{L}$ HJNO

- BLM+0.14 moliL HJNO

- 5umoll HJNO

- BLmo5umoll hJNo

- 50umoliL HJNO

- BLM+50umoliL HJNO

A

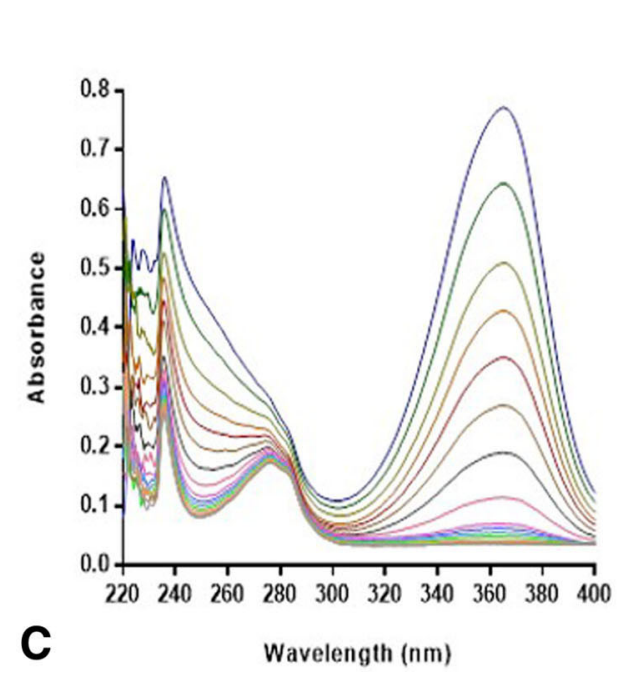

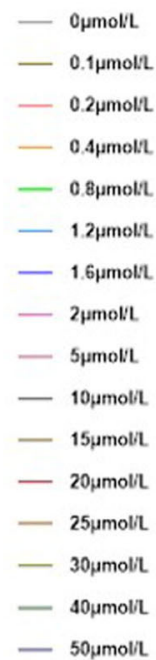

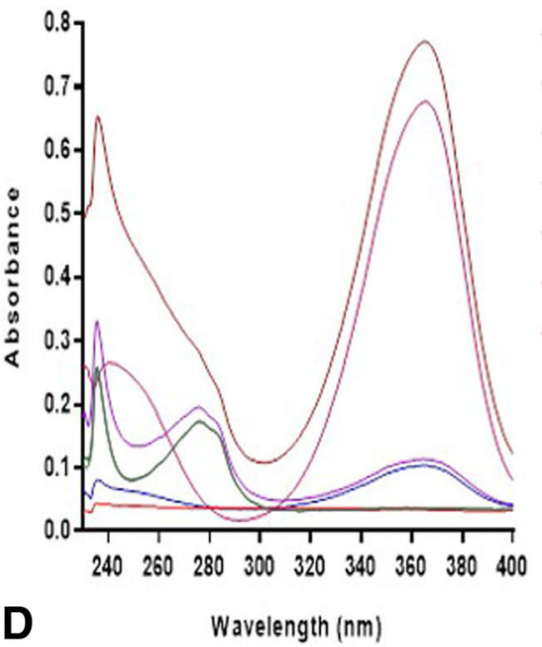

- BLM

- 0.1pmoll MMC

- BLM+0.1umoll MMC

- 5umoli MaC

- BLM+5umoliL MMC

- 50umoliL MMC

- BLM+50umolL uMC

Fig. 5 Effects of HJNO and MMC on the ultraviolet aborption of BLM helicase. a Effects of different concentration of HJNO on the ultraviolet absorption spectrum of BLM helicase $(500 \mathrm{nM})$. $\mathbf{b}$ Effects of HJNO $(0.1 \mu \mathrm{mol} / \mathrm{L}, 5 \mu \mathrm{mol} / \mathrm{L}, 50 \mu \mathrm{mol} / \mathrm{L})$ on the ultraviolet absorption spectrum of BLM helicase $(500 \mathrm{nM})$. c Effects of different concentration of MMC on the ultraviolet absorption spectrum of BLM helicase (500 nM). d Effects of MMC $(0.1 \mu \mathrm{mol} / \mathrm{L}, 5 \mu \mathrm{mol} / \mathrm{L}, 50 \mu \mathrm{mol} / \mathrm{L})$ on the ultraviolet absorption spectrum of BLM helicase $(500 \mathrm{nM})$

thus exerting more intensive inhibiting on $\mathrm{BLM}^{642-1290}$ helicase binding to ssDNA. BLM helicase unzips the double strands towards $3^{\prime}-5^{\prime}$ by binding with one of the partly unwinding strand [39]. Therefore, the strong HJNO inhibiting BLM ${ }^{642-1290}$ helicase binding with ssDNA promotes itself suppressing the DNA unwinding of BLM ${ }^{642-1290}$ helicase.

BLM helicase hydrolyzes ATP to release energy for unwinding DNA by its ATPase [40], thus we have detected the effect of HJNO on the ATPase of BLM ${ }^{642-}$ 1290 helicase. The results showed that HJNO had a certain suppression on the ATPase of BLM $^{642-1290}$ helicase. Since the ATPase of BLM helicase depends on its DNA binding capacity [41], HJNO inhibiting the ATPase of $\mathrm{BLM}^{642-1290}$ helicase is related to its suppression on the DNA binding of BLM $^{642-1290}$ helicase.

We further detected the effect of HJNO on the ultraviolet spectrum of BLM ${ }^{642-1290}$ helicase. The results showed that $\mathrm{HJNO}$ bound to $\mathrm{BLM}^{642-1290}$ helicase and changed its conformation. Theoretically, HJNO inhibited BLM ${ }^{642-}$ ${ }^{1290}$ helicase by changing its conformation, however, it had a significant impact on changing $\mathrm{BLM}^{642-1290}$ helicase conformation when its concentration was $0.1 \mu \mathrm{mol} / \mathrm{L}$, which was dramatically different from suppressive concentration range of $\mathrm{BLM}^{642-1290}$ helicase. The reason might be that HJNO could not inhibit BLM ${ }^{642-1290}$ helicase when its concentration was low, though a certain change 


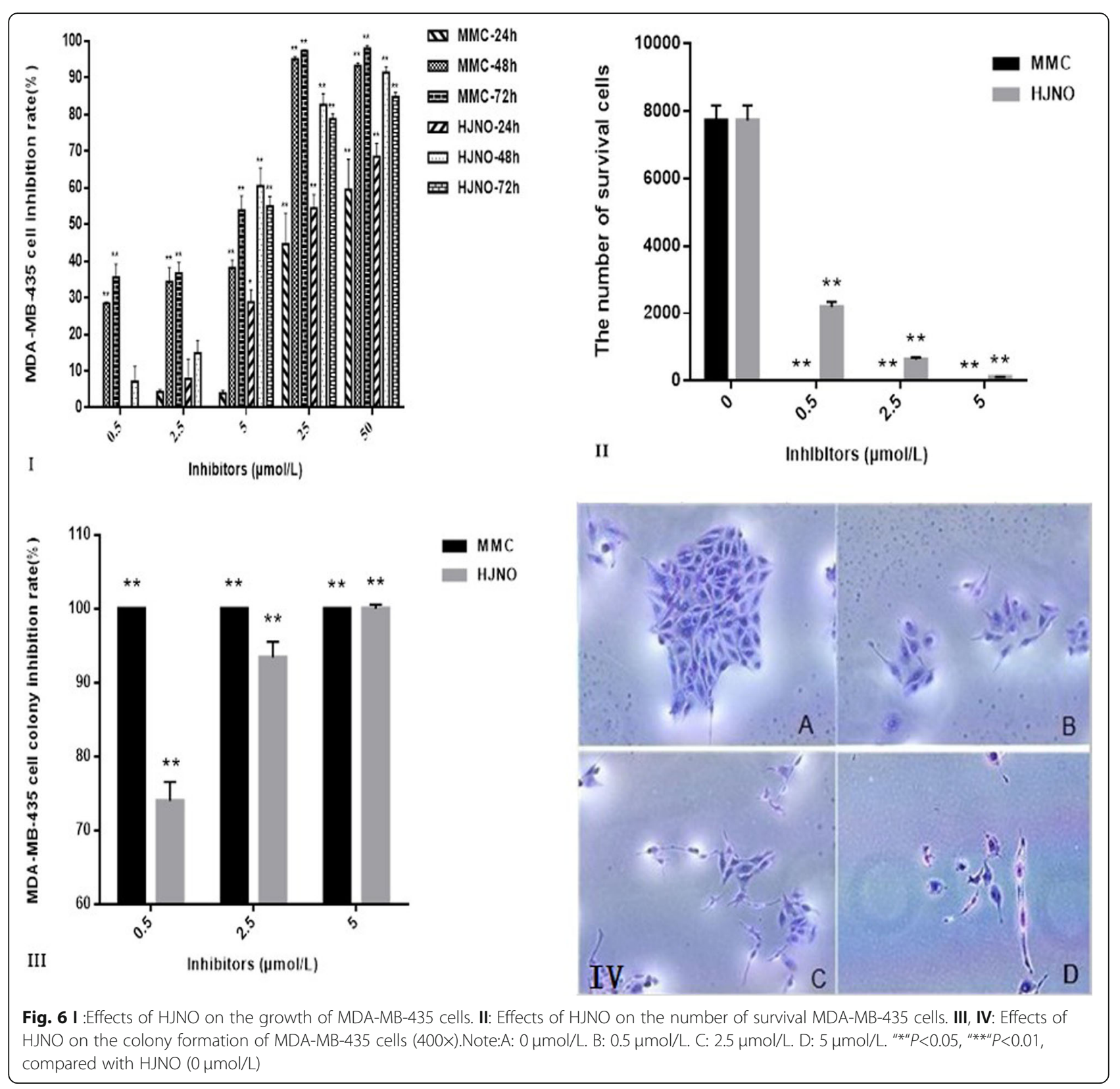

of BLM $^{642-1290}$ helicase conformation had occurred. When HJNO concentration was high, it could inhibit DNA binding of BLM ${ }^{642-1290}$ helicase by changing its conformation, by it inhibiting ATPase and DNA unwinding.

The suppression of HJNO on MDA-MB-435 breast cancer cells expansion

We further confirmed the inhibitory effect of HJNO on tumor growth in MDA-MB-435 breast cancer cell culture a concentration-dependent manner. The results from colony forming assay found that $\mathrm{HJNO}$ also had a strong inhibitory effect on the colony formation of MDA-MB-435 breast cancer cells.
The mRNA and protein expression of BLM helicase in MDA-MB-435 breast cancer cells with HJNO treatment for $24 \mathrm{~h}$ were examined by RT-PCR and ELISA, respectively. And the results displayed an increasing pattern of them, which might contribute to HJNO inhibiting the DNA binding, ATPase and DNA unwinding of BLM helicase. Therefore, in order to resist HJNO soppressing BLM helicase, the mRNA and protein levels of BLM helicase in the MDA-MB-435 breast cancer cells increased through feedback when treated with HJNO. This also suggested that HJNO inhibited MDA-MB-435 breast cancer cells expansion by suppressing BLM helicase. 

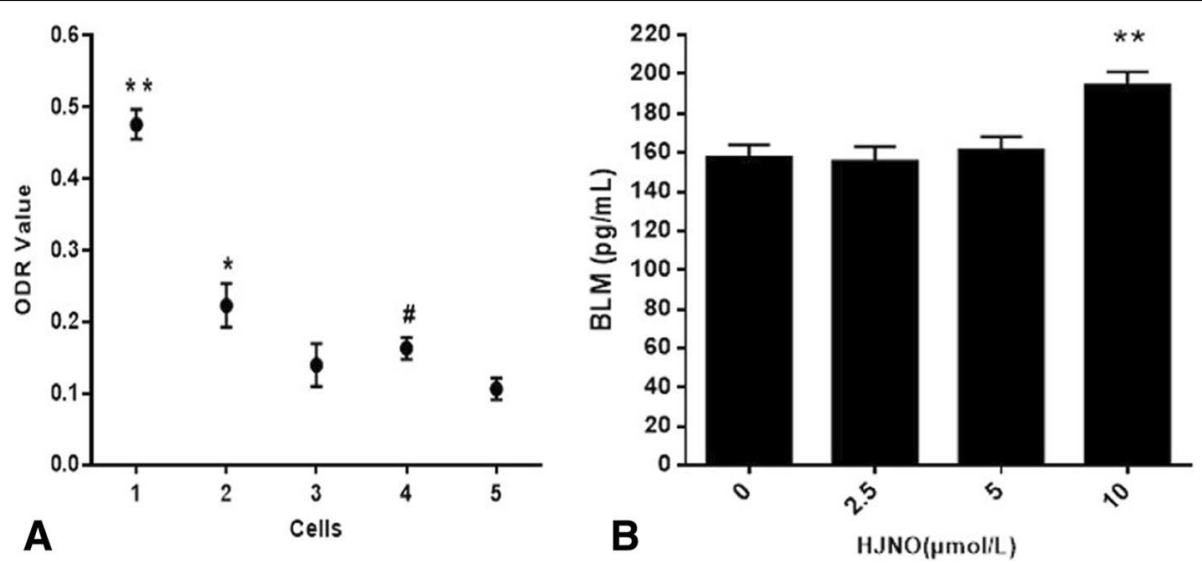

Fig. 7 BLM expression in MDA-MB-435 cells induced by HJNO. a BLM mRNA expression in MDA-MB-435 cells induced by HJNO (optical density ratio). b BLM protein expression in MDA-MB-435 cells induced by HJNO. Note:1: MDA-MB-435 cells (HJNO $10 \mu \mathrm{mmol} / \mathrm{L}$ ). 2: MDA-MB-435 cells (HJNO $5 \mu \mathrm{mol} / \mathrm{L}$ ). 3: MDA-MB-435 cells (HJNO $2.5 \mu \mathrm{mol} / \mathrm{L}) .4$ : MDA-MB-435 cells (HJNO $0 \mu \mathrm{mol} / \mathrm{L}$ ). 5: HUVEC cells (HJNO $0 \mu \mathrm{mol} / \mathrm{L}) .{ }^{*} P<0.05,{ }^{* *} P<0.01$, compared with MDA-MB-435 cells (HJNO $0 \mu \mathrm{mol} / \mathrm{L}) ;{ }^{*} P<0.05$, compared with HUVEC cells (HJNO $0 \mu \mathrm{mol} / \mathrm{L}$ )

\section{Conclusion}

Taken together, we screened out the potential anticancer small molecule HJNO by targeting BLM ${ }^{642-1290}$ helicase and further displayed its suppression on MDA-MB-435 breast cancer cells expansion. This was at least partly associated with HJNO suppressing BLM helicase. Therefore, our study provided some valuable clues for the study of HJNO in the living body and developing HJNO as an anticancer drug.

\section{Abbreviations}

BLM: Bloom syndrome helicase; BS: Bloom syndrome; EMSA: Electrophoretic mobility shift assay; HJNO: A tetrandrine derivative; HRDC: Helicaseribonuclease D-C terminal domain; MDA-MB-435: MDA-MB-435 human breast cancer cell line; MMC: Mitomycin; MTT: Methyl thiazolyl tetrazolium; PBS: Phosphate Buffer solution; RecQ: RecQ helicase; RecQ-Ct: RecQ helicase $C$ terminal; RT-PCR: Reverse transcription-polymerase chain reaction: RTS: Rothmund-Thomson syndrome; WRN: Werner syndrome helicase; WS: Werner syndrome

\section{Acknowledgements}

We thank Dr. Xuguang Xi for his kindly gift of a plasmid and Dr. Yanyan Zhang for her constructive suggestion for the work.

\section{Authors' contributions}

WZ performed Fluorescence polarization technique and the malachite green-phosphate ammonium molybdate colorimetry and ultraviolet spectral scanning. SY performed BLM helicase preparation and DNA binding EMSA. WZ and SY contributed equally to this paper. JHL performed BLM ${ }^{642-1290}$ helicase expression and purification. LB performed MTT method, colony formation assay and cell counting method. HLu and HLi reviewed and modified the manuscript. WP prepared the derivatives in the work and reviewed the manuscript. YJ and ZH performed RT-PCR and ELISA, respectively. $J L L$ performed the design of the work and wrote and modified the manuscript finally. All authors read and approved the final manuscript.

\section{Funding}

This work was financially supported by the National Natural Science Foundation of China (No. 81360349, 81360479), the Science and Technology Department of Guizhou Province (QSZHZ [2006]57, QKHWGZ [2011]7012, QKHJZDZ [2015]2003 and QKHLHZ [2015]7282). The funding agencies played no role in designing research, collecting, analyzing, and interpreting data as well as writing the manuscript.
Availability of data and materials

All data and materials are available without restriction. Researchers can obtain data by contacting the corresponding authors.

Ethics approval and consent to participate

Not applicable.

\section{Consent for publication}

Not applicable.

\section{Competing interests}

The authors declare that they have no competing interests.

\section{Author details}

${ }^{1}$ The First Affiliated Hospital of Guizhou University of Chinese Medicine, Guiyang 550001, People's Republic of China. ²Department of Immunology, Basic Medical College, Guizhou Medical University, 9 Beijing Road, Guiyang 550004, People's Republic of China. ${ }^{3}$ Tissue Engineering and Stem Cell Research Center, Guizhou Medical University, Guiyang 550004, People's Republic of China. ${ }^{4}$ INSERM UMR-S 1165/Paris Diderot 7, Paris, France. ${ }^{5}$ INSERM UMR 1234/Faculté de Médecine et de Pharmacie, Université de Rouen, Rouen, France. ${ }^{6}$ State Key Laboratory of Functions and Applications of Medicinal Plants, Guizhou Medical University, 3491 Baijin Road, Guiyang 550014, People's Republic of China. 'Guizhou Entry-exit inspection and quarantine bureau, Guiyang 550004, People's Republic of China.

Received: 3 July 2018 Accepted: 10 September 2019

Published online: 28 October 2019

\section{References}

1. Siegel RL, Miller KD, Jemal A. Cancer statistics [J], 2016. CA Cancer J Clin. 2016;66(1):7-30.

2. Mo D, Zhao Y, Balajee AS. Human RecQL4 helicase plays multifaceted roles in the genomic stability of normal and cancer cells []]. Cancer Lett. 2018; 413:1-10.

3. Cunniff C, Bassetti JA, Ellis NA. Bloom's syndrome: clinical Spectrum, molecular pathogenesis, and cancer predisposition [J]. Mol Syndromol. 2017:8(1):4-23.

4. Lebel M, Monnat RJ Jr. Werner syndrome (WRN) gene variants and their association with altered function and age-associated diseases [J]. Ageing Res Rev. 2018;41:82-97.

5. Van Maldergem L, Siitonen HA, Jalkh N, et al. Revisiting the craniosynostosis-radial ray hypoplasia association: baller- Gerold syndrome caused by mutations in the RECQL4 gene [J]. J Med Genet. 2006;43(2):148-52. 
6. Furuichi Y. Premature aging and predisposition to cancer by mutations in RecQ family helicases [J]. Ann NY Acad Sci. 2001;928:121-31.

7. Turley $\mathrm{H}, \mathrm{Wu} \mathrm{L}$, Canamero M, et al. The distribution and expression of the Bloom's syndrome gene product in normal and neoplastic human cells [J]. Br J Cancer. 2001;85(2):261-5.

8. Wang $X B, H u L H$. Protein expression of BLM gene and its apoptosis sensitivity in hematopoietic tumor cell strains [J]. J Huazhong Univ Sci Technolog Med Sci. 2008;28(1):46-8.

9. Yan W, Shih JH, Rodriguez-Canales J, et al. Identification of unique expression signatures and therapeutic targets in esophageal squamous cell carcinoma [J]. BMC Res Notes. 2012;5:73.

10. Lu Y, Ge ZW, Liu JL. Expression changes and significance of BLM and RecQ4 helicases in breast cancer stem cells [J]. Shandong Med J. 2017:57(4):17-20.

11. Hengel SR, Spies MA, Spies M. Small-molecule inhibitors targeting DNA repair and DNA repair deficiency in research and cancer therapy [J]. Cell Chem Biol. 2017;24(9):1101-19.

12. Patterson K, Arya L, Bottomley S, et al. Altered RECQL5 expression in urothelial bladder carcinoma increases cellular proliferation and makes RECQL5 helicase activity a novel target for chemotherapy [J]. Oncotarget. 2016;7(46):76140-50

13. Banerjee T, Aggarwal M, Brosh RM Jr. A new development in DNA repair modulation: discovery of a BLM helicase inhibitor [J]. Cell Cycle. 2013;12(5): 713-4.

14. Brosh RM Jr, Karow JK, White EJ, Shaw ND, Hickson ID, Bohr VA. Potent inhibition of Werner and Bloom helicases by DNA minor groove binding drugs [J]. Nucleic Acids Res. 2000;28(12):2420-30.

15. Aggarwal $M$, Sommers JA, Shoemaker RH, et al. Inhibition of helicase activity by a small molecule impairs Werner syndrome helicase (WRN) function in the cellular response to DNA damage or replication stress [J]. PNAS. 2011;108(4):1525-30

16. Duan $L X, X u H Q$, Chen $X$, et al. Effects of estradiol benzoate on the bioactivity of Escherichia coli RecQ helicase [J]. Chin Pharm J. 2011;46(15):1146-50.

17. Duan $L X, X u H Q$, Chen $X$, et al. Effects of testosterone propionate on the structure and function of E.coli RecQ helicase [J]. Chin Pharmacol Bull. 2011; 27(4):467-72.

18. Luo $H$, Chen $X$, Ding $M$, et al. Study on the mechanism of effects of lomefloxacin on biological properties of Bloom syndrome helicase [J]. Prog Biochem Biophys. 2011;38(11):1060-71.

19. Xiang C, Luo H, Lixia D, et al. Effects of mercury on the structure and activity of BLM642-1290 recombinant helicase [J]. Biomed Environ Sci. 2011; 24(1):47-55

20. Luo $\mathrm{H}, \mathrm{Xu} \mathrm{HQ}$, Chen $\mathrm{X}$, et al. Potent in vitro interference of fleroxacin in DNA-binding, unwinding and ATPase activities of Bloom helicase. Biomed Environ Sci. 2013;26(4):231-42.

21. Gao GY, Xiao PG. Review of studies of bisbenzylisoquinoline alkaloid (BBI) on distribution in higher plant and physiological activities [J]. Nat Prod Res Dev. 1999;11(3):96-103.

22. Guo RB, Rigolet $P$, Zargarian L, et al. Structural and functional characterizations reveal the importance of a zinc binding domain in Bloom's syndrome helicase [J]. Nucleic Acids Res. 2005;33(10):3109-24

23. Liu YZ, Huang L, Sun Q, et al. Syntheses and anti-cancer activities of derivatives of tetrandrine and fangchinoline [J]. Chem Res Chinese U. 2014; 30(6):937-40.

24. Lan JJ, Wang N, Huang L, et al. Design and synthesis of novel tetrandrine derivatives as potential anti-tumor agents against human hepatocellular carcinoma [J]. Eur J Med Chem. 2017;127:554-66.

25. Song TR, Ben-David Y, Pan WD. Design, synthesis, and bioactivity investigation of tetrandrine derivatives as potential anti-cancer agents [J]. MedChemComm. 2018:9:1131-41.

26. Liu YZ, Xia B, Lan JJ, et al. Design, synthesis and anticancer evaluation of fangchinoline derivatives [J]. Molecules. 2017;22(11):1923-35.

27. Morimoto W, Kaneko $\mathrm{H}$, Isogai $\mathrm{K}$, et al. Expression of BLM (the causative gene for Bloom syndrome) and screening of Bloom syndrome [J]. Int J Mol Med. 2002;10(1):95-9.

28. Lu XM, Chen DJ, Wang GK, et al. Studies on the reaction of norfloxacin with ovalbumin [J]. Spectrosc Spectr Anal. 2009;29(1):236-9.

29. Zhang GC, Fan S. Interaction between chromium (VI) and hemoglobin: spectroscopic approach [J]. Chinese J Inorg Chem. 2009;25(7):1199-204.

30. Kitano K. Structural mechanisms of human RecQ helicases WRN and BLM [J]. Front Genet. 2014:5:366.
31. Patel DS, Misenko SM, Her J, Bunting SF. BLM helicase regulates DNA repair by counteracting RAD51 loading at DNA double-strand break sites [J]. J Cell Biol. 2017;216(11):3521-34

32. Xu W, Debeb BG, Lacerda L, Li J, Woodward WA. Tetrandrine, a compound common in Chinese traditional medicine, preferentially kills breast cancer Tumor Initiating Cells (TICS) in vitro [J]. Cancers (Basel). 2011;3(2):2274-85.

33. Zhou LY, Ren WY, Liao YP, et al. Study on relationship between IGFBP-5/p53 axis and anti-proliferation effect of tetrandrine in MCF-7 cells [J]. Chin Pharmacol Bull. 2018;34(1):38-43.

34. Liu W, Kou B, Ma ZK, Tang XS, Lv C, Ye M, Chen JQ, Li L, Wang XY, He DL. Tetrandrine suppresses proliferation, induces apoptosis, and inhibits migration and invasion in human prostate cancer cells [J]. Asian J Androl. 2015;17(5):850-3.

35. Li WS, Shi CR, Du Y. Study on the efficacy of Tetrandrine in inducing the apoptosis of neuroblastoma cells [J]. J Clin Pediat. 2006;24(6):512-5.

36. Wang DX, Yuan SX, Wu QX, et al. Study on the relationship between insulin-like growth factor binding protein 5 and the anti-proliferation effect of tetrandrine in human colon cancer cells [J]. Chin Pharmacol Bull. 2015; 31(10):1403-8.

37. Ren WY, Chen QZ, Zhou LY, et al. Study on the relationship between the anti-proliferation effect of tetrandrine and TGF- $\beta 1$ in human colon cancer cells [J]. Chin Pharmacol Bull. 2017:33(9):1227-33.

38. Futami K, Furuichi Y. RECQL1 and WRN DNA repair helicases: potential therapeutic targets and proliferative markers against cancers [J]. Front Genet. 2015;5:441.

39. Karow JK, Chakraverty RK, Hickson ID. The Bloom's syndrome gene product is a 3'-5' DNA helicase [J]. J Biol Chem. 1997;272(49):30611-4.

40. Waksman G, Lanka E, Carazo JM. Helicases as nucleic acid unwinding machines [J]. Nat Struct Biol. 2000;7:20-2.

41. Roychowdhury A, Szymanski MR, Jezewska MJ, Bujalowski W. Mechanism of NTP hydrolysis by the Escherichia coli primary replicative helicase DnaB protein. II [J]. Nucleotide Nucleic Acid Specificities Biochem. 2009;48(29): 6747-63.

\section{Publisher's Note}

Springer Nature remains neutral with regard to jurisdictional claims in published maps and institutional affiliations.
Ready to submit your research? Choose BMC and benefit from:

- fast, convenient online submission

- thorough peer review by experienced researchers in your field

- rapid publication on acceptance

- support for research data, including large and complex data types

- gold Open Access which fosters wider collaboration and increased citations

- maximum visibility for your research: over $100 \mathrm{M}$ website views per year

At $\mathrm{BMC}$, research is always in progress.

Learn more biomedcentral.com/submission 